\title{
A FELSŐOKTATÁSI HALLGATÓK ÖNKÉNTESSÉGE ÉS A HALLGATÓK CSALÁDTERVEINEK ÖSSZEFÜGGÉSEI*
}

\section{Fényes Hajnalka - Markos Valéria}

\section{ÖSSZEFOGLALÓ}

Tanulmányunkban a Család és karrier kutatás keretében vizsgáljuk, hogy a felsőoktatási hallgatók önkéntessége mennyiben jár együtt a házasság tervezésével (kontra egyéb párkapcsolati tervek) és az átlag feletti gyermekszámtervekkel. Hipotézisünk szerint az önkéntesség és az átlagnál több gyermek tervezésének hátterében egy közös (általunk nem mért) ok állhat, a diákok altruista attitűdje, emiatt a két tényező között együttjárás figyelhető meg. Regressziós eredményeink szerint a házasság tervezésére elsősorban a vallásosság, a jobb anyagi helyzet, az apa magasabb iskolázottsága, valamint a hallgatótársakkal való kiterjedt kapcsolatok voltak pozitív hatással. Azonban a nagyobb tervezett gyermekszám esélyét növelte a diákok vallásossága mellett az is, ha valaki egyetemi évei alatt önkénteskedett. Meggyőződésünk szerint tehát az altruizmus, a tolerancia és a segítőkészség fejlesztése a diákok körében pozitív hatással lehet mind a családalapítási tervekre, mind az önkéntességre. Fontos megjegyezni azonban, hogy itt csak a házasság és az átlagosnál több gyermek tervezését vizsgáltuk, ám mint azt a szakirodalomból is tudjuk, ezek a tervek nem biztos, hogy meg is valósulnak. Tárgyszavak: önkéntesség, felsőoktatási hallgatók, házasság és családtervek, kvantitatív elemzés

Fényes Hajnalka, Debreceni Egyetem, Szociológia és Szociálpolitika Tanszék E-mail: fenyesh@gmail.com Markos Valéria, Debreceni Egyetem, Nevelés és Müvelődéstudományi Doktori Program E-mail: markosvaleria.90@gmail.com

*Az Emberi Erőforrások Minisztériuma ÚNKP-18-3-III-DE-240. kódszámú Új Nemzeti Kiválóság Programjának támogatásával készült. 


\section{BEVEZETÉS}

Tanulmányunkban az önkéntesség és a családtervek összefüggéseit (lehetséges együtt járását) vizsgáljuk a felsőoktatási hallgatók körében. A családi állapot és a gyermekszám kapcsolata az önkéntességgel fontos kutatási terület a felnőtt lakosság körében, a nemzetközi és a hazai szakirodalomban. Kutatásunk újszerüségét adja, hogy mi a felsőoktatási hallgatók család- és párkapcsolati terveivel hozzuk összefüggésbe a diákok önkéntes munkában való részvételét. Hipotézisünk szerint a hallgatók önkéntes munkájában jelenlevő altruista attitüd családalapítási terveikben is megjelenhet, és ez a mögöttes tényező okozhatja a két dolog együtt járását.

A tanulmány elméleti részében elsőként a párkapcsolati és családalapitási jellemzők alakulását vizsgáljuk a magyarországi felnőtt népesség körében, majd a felsőoktatási hallgatók párkapcsolati és családterveit mutatjuk be az eddigi hazai kutatások alapján. Foglalkozunk az önkéntesség általános jellemzőivel, majd a felsőoktatási hallgatók önkéntes tevékenységeivel. Ezután a családi állapot, a gyermekszám és az önkéntesség összefüggéseit vizsgáljuk a felnőtt lakosság körében a szakirodalom alapján. Empirikus munkánkban elsőként a hallgatók önkéntességének gyakoriságát és annak motivációit tárjuk fel, majd vizsgáljuk ezek kapcsolatát a családtervekkel. Ezután regressziós modellek segítségével két függőváltozóra, a házasság kontra egyéb párkapcsolat tervezésére, valamint az átlagosnál több vagy kevesebb gyermek tervezésére vonatkozó hatásokat tárjuk fel, és az önkéntesség mellett számos más magyarázóváltozót is bevonunk. Elméleti munkánk végén hat hipotézist fogalmazunk meg a szakirodalomra támaszkodva, amelyeket az összegzésben ellenőrzünk.

\section{PÁRKAPCSOLATI ÉS CSALÁDALAPÍTÁSI JELLEMZÖK ALAKULÁSA MAGYARORSZÁGON}

1970-es évek közepén magas házasodási arány jellemezte a magyar társadalmat; az emberek csaknem 95\%-a életében legalább egyszer megházasodott. Ennek okát azzal magyarázták, hogy azokban az években léptek családalapítási korba a Ratkó-korszak gyermekei. Ugyanakkor számos népesedéspolitikai intézkedés és az életszínvonal emelkedése is hozzájárult a házasodási kedv növekedéséhez. A házasságkötés elhatározásában fontos tényezőként jelent meg a fiatalok anyagi érdekeinek szem előtt tartása, a meghatározó ideológia, valamint a szülők házasodásra ösztönző attitűdje (Somlai - Tóth 2002). 
Az utóbbi évtizedekben jelentős csökkenést mutatott a házasságkötések száma. A párkapcsolati tartalmak átalakulásának oka a fiatalok tanulmányainak kitolódásával magyarázható. Az oktatási intézményekben eltöltött évek meghosszabbodása, a munkaerőpiacra való belépés késleltetésének következtében a családalapítás is kitolódik. Annak ellenére, hogy a házasodási hajlandóság csökkenni látszik a fiatalok körében, a házasság megítélése és a gyermekvállalási hajlandóság pozitív képet mutat. A fiatalok családcentrikusak, ugyanakkor a tervezettnél később és kevesebb gyermeket vállalnak, illetve kevesebben kötnek házasságot, mint ahány tervezik (Kapitány 2002, KSH 2012, Engler 2014).

Magyarországon a házasságkötések mélypontja 2010-ben volt, azóta folyamatos javulás volt tapasztalható. Ugyanakkor 2017-ben megtorpant az emelkedés, és 2,5\%-kal csökkent a házasságkötések száma 2016-hoz képest. A 2010 és 2016 közötti növekedést több tényező okozhatta, így a 2009-es gazdasági válság lecsengése, a gazdasági helyzet javulása, az elhalasztott házasságok pótlása, valamint a házasokat támogató kormányzati rendelkezések és támogatások bevezetése (Murinkó - Rohr 2018).

Napjainkban sokan választják a hosszabb távú élettársi kapcsolatot és a házasság nélküli gyermekvállalást is. Ezek a jelenségek az 1990-es években kezdtek általánossá válni, de már a 1970-es években megkezdődtek. Paradoxon, hogy míg a családi életformák pluralizálódása figyelhető meg (Somlai 2013), továbbra is tradicionális értékek uralkodnak a magyar lakosság körében (Pongráczné - S. Molnár 2011). A társadalom többsége jobban elfogadja a házasságot, mint az élettársi kapcsolatot, de mérsékelten nő a házasság nélküli együttélés elfogadottsága is. 2013-as adatok szerint az inkonzisztencia csak látszólagos, és az egyéni élethelyzettől erősen függ, hogy mi az elfogadott. Rohr (2017) a felnőtt népesség véleményeit vizsgálva azt az eredményt kapta, hogy az élettársi kapcsolatok elfogadottsága az aktuális párkapcsolati helyzettel (házas, elvált, hajadon/nőtlen, özvegy) és az életkorral függött össze leginkább, de befolyásolta a vallásosság és az egyén lakhelyének településtípusa is.

Az ezredforduló óta 2016-ig minden életkori csoportban csökkent a házasok aránya, ugyanakkor nőtt az élettársi kapcsolatok aránya. Ez a változás a korábban házas 30-40 éves korosztályt is érintette; a házasok aránya a 40-es éveikben járók alig 50\%-át teszik ki. A 25-39 évesek negyede, a 40-44 évesek ötöde él élettársi kapcsolatban. Látható tehát, hogy 40 év fölött is tartósan jelen van ez a fajta párkapcsolati forma (Murinkó - Rohr 2018).

Elsősorban a fiatalokat jellemzi az ún. látogató partnerkapcsolat (együttélés nélküli párkapcsolat). Az Életünk fordulópontjai kutatás 2016-os adatai alapján a 
látogató kapcsolatban élők 40\%-a 30 év alatti, 18\%-a a 30-as, míg 20\%-a a 40-es éveiben járt, míg ötödük 50 év feletti volt (Murinkó - Rohr 2018).

Magyarországon az elmúlt években a gyermekek számának tekintetében nem mutatható ki növekedés, ugyanakkor a gyermekvállalási kedv nőtt. Ennek oka a gyermekvállalási korban lévő nők számának csökkenése. Míg 2011-ben a teljes termékenységi arányszám 1,23 volt, addig 2017-re 1,49-ra emelkedett, ami még mindig nem éri el a népesség újratermelődéséhez szükséges 2,1 értéket. A gyermekvállalási hajlandóságot az iskolai végzettség is jelentősen befolyásolja. Az elmúlt időszakban elsősorban az alacsonyabb iskolázottságú fiatalok terveztek több gyermeket. Nemcsak a gyermekvállalási kedvet, hanem a gyermekszámot is befolyásolja az iskolai végzettség. A középfokú végzettségűek körében az egygyermekes, a felsőfokú végzettségüeknél a kétgyermekes, míg az alapfokú végzettségüeknél a három- vagy többgyermekes családmodell a leggyakoribb (Kapitány - Spéder 2018, Monostori - Murinkó 2018).

\section{A FELSŐOKTATÁSI HALLGATÓK PÁRKAPCSOLATI ÉS CSALÁDALAPÍTÁSI TERVEI}

A kutatások azt mutatják, hogy a fiatalok prioritásokat állítanak fel a jövőjükkel kapcsolatban. Egy, a felsőoktatási hallgatók család- és karrierterveiről szóló kutatás szerint kimutatható, hogy a diákok saját elvárásaiknak szeretnének leginkább megfelelni, diplomájukat megszerezni, szakmai kapcsolataikat megalapozni, és váltakozik életükben a család és a karrier prioritása (Mohácsi - Juhász 2017)

A szakmai (munkaerőpiaci elhelyezkedés, karrierépítés, továbbtanulás) és magánéleti tervek (párkapcsolat, gyermekvállalás) nem egymás mellett, hanem egymást követve jelennek meg. Kiemelten jellemző ez a magas iskolai végzettséget elérő hallgatókra. Emellett az iskolai végzettség emelkedésével nő a kívánt és a realizálódott gyermekszám közötti különbség. Azaz, minél magasabb iskolai végzettséggel rendelkezik a fiatal, annál kisebb az esélye, hogy megvalósítsa a családalapítással kapcsolatos terveit (Kopp - Skrabski 2003, Engler 2018).

A Család és karrier kutatás eddigi eredményei szerint a felsőoktatási hallgatók többsége minimum egy gyermeket szeretne, ugyanakkor a hallgatók többsége kétgyermekes családmodellben képzeli el az életét, továbbá a nők körében gyakoribb a több gyermek tervezése. A tervezett gyermekszámot a család nagysága (testvérek száma) és a család szubjektív anyagi helyzete is befolyásolja. Kimutatható, hogy azok, akik rosszabb anyagi helyzetben élnek, 
bizonytalanabbak a gyermekvállalással kapcsolatban, és legfeljebb egy gyermeket terveznek (Engler 2018).

A fiatalok magánéleti és családalapítási tervei kapcsán regionális különbségek is láthatók. A kisebb településen élők és a kisebb vidéki egyetemek hallgatói számára fontosabb a házasságkötés. A vidéki egyetemek hallgatói a diplomaszerzést követő években szeretnének gyermeket vállalni (25-30 év), ezzel szemben a fővárosi hallgatók rugalmasabbak a gyermekvállalás időzítésével kapcsolatban (Fináncz 2018).

A párkapcsolati tervek és a munkaértékek kapcsán Bocsi (2018) eredményei szerint a férfiak esetében egyaránt fontos a karrierépítés, a munkába való kiteljesedés és a párkapcsolat. Azok a nők, akik fontosabbnak tartják az elköteleződést (pl. házasságot terveznek), a munkaértékek tekintetében meghatározó, hogy a kollégák barátságosak legyenek, illetve a munkahely jó hangulatú legyen, valamint a munkát és a családot össze tudják egyeztetni. A férfiak munkaértékei és a tervezett gyermekszám tekintetében az adatok azt mutatják, hogy a nagyobb tervezett gyermekszám a munka társas beágyazottságával, az önálló és felelősségteljes munkával, illetve egyes intrinzik értékekkel, mint a sikerélmény és az érdekes munka áll kapcsolatban. A nők munkaértékei kapcsán az látható, hogy a karrier, a biztos munkahely és a magas kereset nem függ össze a tervezett gyermekszámmal. Az adatok szerint azonban a kettő vagy annál több gyermeket tervező nők körében a munka szociális, társas dimenziója a leglényegesebb (Bocsi 2018).

\section{AZ ÖNKÉNTESSÉG JELLEMZÖI HAZAI ÉS NEMZETKÖZI KUTATÁSOK ALAPJÁN}

2001-ben az ENSZ, az önkéntesek nemzetközi éve alkalmából kibocsátott egy dekrétumot, amelyben megfogalmazta az önkéntesség jellemzőit és kritériumait. Az önkéntességről hazánkban a 2005. évi LXXXVIII. törvény szól, amely kimondja, hogy önkéntesnek számít az a személy, aki anyagi ellenszolgáltatás nélkül végez közérdekű tevékenységet egy fogadószervezetnél. A végzett tevékenységnek tehát formális, szervezett keretek között kell folynia. Ugyanakkor a szakirodalom szerint létezik szervezeten kívüli, informális önkéntes tevékenység is (Czike - Szabóné 2010, Fényes 2015).

A nemzetközi szakirodalom az önkéntesség négy fő ismérvét különbözteti meg, tanulmányunkban mi is ezt a definíciót fogadjuk el (Cnaan - Amrofell 1994, Wilson 2000, Dekker - Halman 2003, Handy et al. 2010): 
1. Önkéntes tevékenység nem kötelező, az egyén önként, szabad akaratából és belső indíttatásból végzi.

2. Az egyén tevékenységéért cserébe nem jár anyagi ellenszolgáltatás.

3. Az önkéntesség elsősorban más személy, csoport vagy a társadalom hasznát, a közjót szolgálja.

4. A negyedik kritérium Wilson (2000) és Voicu - Voicu (2003) szerint az, hogy az önkéntesség általában szervezett keretek között folyik.

Az Európai Parlament Kutatói Szolgálat szerint 2016-ban Szlovéniában, Dániában, Írországban és Hollandiában volt a legmagasabb az önkéntesek aránya, míg Lengyelországban, Görögországban és Magyarországon a lakosság mindössze egyhatoda önkénteskedett (Volunteurope 2018).

Kelet-Közép-Európa és Nyugat-Európa közötti különbség az önkéntességben is megnyilvánul. A nyugati országokban, ahol a demokrácia stabil, az önkéntesség aránya jóval magasabb, mint a keleti országokban (Juknevičiusa - Savicka 2003).

Mindazonáltal Bartal (2008) vizsgálata és a Központi Statisztikai Hivatal (2016) adatai alapján látható, hogy Magyarországon az önkéntesek aránya nőtt a lakosság körében a rendszerváltás után. Azonban az önkéntességnek nemcsak számbeli alakulásában történtek változások, hanem társadalomstatisztikai jellemzőiben is. Míg a rendszerváltozást követően a férfiak, később inkább a nők önkénteskedtek nagyobb arányban. Az életkor szempontjából egyre népszerübb az idősebb, azaz a nyugdíjas korosztály körében a fizetetlen munkavégzés, míg a családi állapot tekintetében ma is, mint ahogy húsz évvel korábban, inkább a házasok önkénteskednek. Míg a rendszerváltás idején a felsőfokú végzettségüek önkénteskedtek többen, mára a szakmunkás és szakközépiskolai végzettségüek körében is népszerüvé vált. A településtípusok esetében hasonló tendencia mutatható ki, mint Európa szerte; inkább a vidéki lakosságra jellemző az önkéntesség, mint a városok lakosaira.

Bartal (2010) újabb eredményei szerint alig van különbség nemenként az önkéntesség gyakoriságában, viszont Czike és Kuti 2006-os eredményei szerint a felnőtt lakosság körében épp a férfiak körében volt gyakoribb. Ennek oka lehetett, hogy a nők segítő attitűdje nem csak az önkéntességben jelenik meg, hanem családi feladataikban is. Emellett az önkéntesség területe is eltér nemenként, a segítő célú, szociális intézményekben folyó önkéntes munka inkább a nőkre, a későbbiekben definiált új típusú önkéntesség pedig inkább a férfiakra jellemző (Czike - Kuti 2006).

Egy friss kutatás szerint nemenként, a 15-74 éves korosztályban a nők nagyobb hajlandósággal végeznek önkéntes munkát, mint a férfiak, bár a különb- 
ség kicsi (a nők 35\%-a, a férfiak 33,6\%-a). Különbség mutatkozik abban is, hogy szervezett keretek között vagy közvetlenül végez valaki segítő tevékenységet. Míg a nők ez utóbbit, azaz a közvetlen segítségnyújtást részesítik előnyben, addig a férfiak többsége a szervezett keretek között folyó munkát preferálja (Váradi 2017).

Perpék Éva (2012) azt vizsgálta Magyarországon, hogy mely tényezők képesek befolyásolni az önkéntességet a felnőtt lakosság körében. Eredményei szerint a magasabb iskolai végzettség és a gazdasági aktivitás növeli a másokon való segítési hajlandóságot. Mindemellett a vallásosság, kiváltképp a templomba járás növeli az önkéntes munkavállalás esélyét. Azonban a társadalmi tőke nagyobb mértékben képes fokozni az önkéntes hajlandóságot, mint a szociodemográfiai tényezők. A társadalmi tőkén érti a kiterjedtebb baráti kört, a formális és nem formális interakciókat, a családi kapcsolatokat, a több gyermek vállalását, a vallásosságot, a szervezeti tagságot, a személyes társasági kapcsolathálózatot és a másokba vetett bizalmat (Perpék 2012).

A szakirodalom szerint (Voicu - Voicu 2003, Ruiter - De Graaf 2006, Wilson - Musick 1997, Fényes 2015, Pusztai - Fényes 2014) az önkéntesség és a vallásosság között szoros összefüggés mutatkozik. Azok, akik vallási közösségek tagjai, gyakrabban vesznek részt önkéntes tevékenységben, mint azok, akik nem tartoznak ilyen közösségekbe. Ennek hátterében az áll, hogy az egyházi közösségekben több információ áll rendelkezésre önkéntes munkalehetőségekről, emellett a mások segítésének fontossága egyfajta erkölcsi kötelesség is a közösség tagjainak számára.

\section{AZ ÖNKÉNTESSÉG ÉS A FIATALOK}

A Flash Eurobarométer 2015-ös adatai szerint jelentős eltérések mutathatók ki országonként, a fiatalok önkéntes tevékenységében. Írországban (42\%), Dániában (39\%) és Hollandiában (38\%) a 15-30 év közötti fiatalok több mint egyharmada vett részt szervezett önkéntes tevékenységekben az elmúlt egy évben, míg Bulgáriában (10\%), Görögországban (13\%) és Svédországban (15\%) önkénteskedtek a legkevesebben. Magyarországon a megkérdezettek 18\%-a végzett önkéntes tevékenységet, ami jóval elmarad az EU-átlagtól (25\%). Ha megvizsgáljuk a válaszadók szociodemográfiai hátterét, láthatjuk, hogy azok a fiatalok, akik 20 évesen vagy idősebb korban hagyták el az oktatási rendszert (azaz feltehetőleg magasabb iskolai végzettségűek), nagyobb valószínűséggel vettek részt önkéntes munkában (26\%), mint azok, akik 16-19 éves korukban 
(20\%) vagy 15 éves koruk előtt (15\%). Az önkéntességben való részvétel szintén alacsonyabb a fizikai munkát végzők körében (17\%), míg a többi foglalkozási csoportban magasabb (25-27\%). A vidéken élő fiatalok nagyobb valószínüséggel önkénteskednek (29\%), mint a városban élők (24\%). Az életkor tekintetében is különbség mutatkozik: a 15-19 évesek 29, a 20-24 évesek 26, míg, a 25-30 évesek 23 százaléka volt önkéntes (European Youth 2015).

A felsőoktatási hallgatók körében végzett kutatások szerint az önkéntesség aránya a fiataloknál fokozatosan nő (Fényes 2015, Fényes - Markos 2016, Markos 2018). A Debreceni Egyetemen 2005-ről 2010-re az önkéntesek száma több mint kétszeresére emelkedett (2010-ben a hallgatók 26\%-a végzett önkéntes munkát egyetemi tanulmányai alatt), ugyanakkor nemenként alig volt különbség a két adatfelvétel során, annak ellenére sem, hogy a vallásosság növeli az önkéntesség előfordulását (Pusztai - Fényes 2014), és a nők gyakoribb közösségi vallásgyakorlók. Az eredményt még az sem befolyásolja, hogy a felsőoktatásban tanuló férfiak általában jobb társadalmi háttérrel érkeznek, és az önkéntesség is a kedvezőbb hátterü diákokra jellemző.

A hazai (Czike - Bartal 2004, Czike - Kuti 2006) és nemzetközi kutatások (Wollebek - Selle 2003, Hustinx 2001) egyaránt vizsgálják, hogy mi motiválja a fiatalokat az önkéntes munkavállalásra. Az önkénteseket korábban jellemző altruisztikus motivációkat (a társadalom számára hasznos legyen, másokért való cselekvés, a saját és mások jogainak és érdekeinek védelme) egyre inkább felváltják az önérdekű, szakmai tapasztalatszerző, ún. új típusú önkéntes motivációk. Ilyen individualisztikus motiváció többek között a kapcsolatépítés, a hasonló érdeklődésű körüekkel való találkozás, a másokkal közös szabadidős, sporttevékenység végzése, az információszerzés, a készségfejlesztés és a munkatapasztalat-szerzés.

Fényes és munkatársai (2012) az új típusú önkéntes munka vonatkozásában vizsgálták a bourdieu-i tőkefajták konvertálását a fiatalok körében. Az önkéntes munkának nem közvetlen célja a gazdasági tőkenövelés, így inkább koncentrálódhat a kulturális, illetve a társadalmi/kapcsolati tőke bővítésére. Ha valaki szocializációja során nem rendelkezik elegendő kulturális tőkével, az önkéntes munkavégzés során szerzett tudás, tapasztalat, információ segítheti az egyént egyfajta inkorporált kulturális tőkéhez jutni. Ennek elsajátítása hosszú folyamat. Időt, energiát fektet be az egyén, amely beruházásáldozatokkal jár, ugyanakkor az inkorporált tőke a személyiség részévé válik. A kulturális tőke mellett, ha valaki nem rendelkezik elegendő kapcsolati tőkével, annak hiányát az önkéntességgel pótolni tudja. Az önkéntesség által szerzett kulturális és kapcsolati tőkét pedig a későbbi álláskeresés során kamatoztatni tudja, így végső soron gazdasági tőkévé tudja konvertálni a jövőben. 


\section{A CSALÁDI ÁLLAPOT, A GYERMEKSZÁM ÉS AZ ÖNKÉNTESSÉG ÖSSZEFÜGGÉSEI A FELNÖTT LAKOSSÁG KÖRÉBEN}

Granovetter (1973) szerint az interperszonális kapcsolatok erőssége a minimális ismeretségtől a barátságon át, a szoros rokoni szálakig terjedhet. A kapcsolat intenzitását több tényező határozza meg, mint például az együtt eltöltött idő hossza, a kapcsolat érzelmi erőssége és közvetlensége, vagy a reciprocitás mértéke. Granovetter (1983) az erős kötéseken túl (családtagok, barátok) megkülönbözteti az ún. gyenge kötéseket, amelyek során az egyén a sajátjától eltérő társadalmi csoport tagjaival kerül kapcsolatba. Az önkéntesség mind a gyenge, mind az erős kötések kialakításában és fenntartásában fontos eszköz lehet.

Az önkéntes munkavégzés során kialakitott viszonyok segíthetik a munkaerőpiaci kapcsolatok kialakítását, de a baráti vagy párkapcsolatok kialakitásának is kedvezhet, amely a jövőben, házasság formájában társadalmilag is intézményesülhet. Azonban azok az egyének, akiknek az önkéntesség során fő cél az új emberekkel vagy egy új partnerrel való megismerkedés volt, az új kapcsolat kialakítását követően akár félbe is szakithatják tevékenységüket, hiszen a motivációjuk jelentősen lecsökken (Lancee - Radl 2014).

Einolf és Philbrick (2014) vizsgálták, hogy a házasság vajon elszakítja-e az egyént a társadalomtól, vagy épp ellenkezőleg, hozzájárul-e a társadalmi tőke növeléséhez. Fő kutatási céljuk annak vizsgálata volt, hogy a házasság hogyan befolyásolja az önkéntességet és a jótékonysági hajlandóságot. A 2001 és 2009 között lefolytatott vizsgálat során kimutatták, hogy a férfiak a házasságot követő kezdeti időszakban nagyobb valószínűséggel jótékonykodtak, mint a házasságot megelőzően, míg a nők ezzel ellentétben kevésbé adományoztak és kevesebbet is önkénteskedtek, mint korábban.

Reed és Selbee (2001) szerint a házasságot követően az egyének önkéntességgel kapcsolatos attitűdjei jelentősen átalakulnak. A gyermek(ek) születésével járó plusz kötelességek, elvárások és a szülői szereppé válás jelentős hatással lehetnek az önkéntes munkavégzés gyakoriságára. A gyermek meglétén túl, a gyermek kora is befolyásolja az önkéntességet. A gyermek nélküli, ám házas párok önkéntességi aktivitását ugyanaz jellemzi, mint az egyedülállókat, azonban az is kimutatható, hogy a házaspárok kevesebbet önkénteskednek házasságuk korai szakaszában, hisz akkor inkább a saját közös életükre koncentrálnak, mint a nagyobb közösség érdekeire.

Az önkéntességet a házasság pozitívan is befolyásolhatja azáltal, hogy az egyik fél új környezetbe, közösségbe vezetheti partnerét, amely új kapcsola- 
ti tőkeként kamatozhat a másik fél számára. Az önkéntesség gyakoriságában különbség mutatkozik a házastársi és az élettársi kapcsolatok mentén. Ennek értelmében Rotolo és Wilson (2006) szerint az önkéntes munka gyakoribb a házastársak körében, mivel az élettársak élete kevésbé kötődik egymáshoz, mint a házastársaké (Lancee - Radl 2014).

A korábban házasságban élők, majd egyedül maradtak (Özvegyek, elváltak) számára az önkéntesség lehetőséget nyújthat kapcsolatok kialakítására, fenntartására, illetve olyan szociális igények kielégítésére, amelyet korábban az egyén partnerétől megkapott (Lancee - Radl 2014). Li (2007) szerint azonban az özvegység esetén csak az első néhány évben nő meg az önkéntes munkavégzés iránti hajlandóság.

Nesbit (2011) megállapítja, hogy az egyén önkéntességi hajlandóságát életében négy életciklus befolyásolhatja legjelentősebben: a gyermek születése, a válás, az özvegység és egy másik háztartástag halálának bekövetkezése. A válás tekintetében kimutatható, hogy az elvált férfiak nagyobb valószínüséggel és több munkaórában önkénteskednek, mint az elvált nők.

Bartal (2010) egy hazai mintában vizsgálta, hogy milyen összefüggés mutatható ki a családi állapot és az önkéntes munkavégzés között. Az eredmények szerint az önkéntesek többsége házas (50\%), míg a második legnépesebb csoport a hajadonok/nőtlenek csoportja (26\%) volt.

Annak oka, hogy a házasságban élők magasabb arányban önkénteskednek, mint az elváltak, a nőtlenek, a hajadonok vagy az özvegyek, az, hogy az együttélés miatti áldozatvállalás normái és a személyes példamutatás hangsúlyosabban jelenik meg a családokban. A házasok gyakrabban élnek idős, beteg, gondozásra szoruló családtagjaiktól külön háztartásban, akiknek segítségre van szükségük. A gyermeknevelés és az ezzel járó többletfeladatok nagyobb arányban igénylik a szülői támogatást és az önzetlen tevékenységeket (Váradi 2017).

Bartal (2010) kimutatta, hogy a gyermekszám növekedésével arányosan mérséklődik az önkéntesek száma. Az adatok szerint a gyermektelenek 87, az egygyermekes családok 89, a kétgyermekesek 90, míg a három- és többgyermekes családok 91\%-a nem végzett önkéntes tevékenységet az elmúlt évben (Bartal 2010).

A 2008-as Európai értékvizsgálat eredményeihez hasonlóan, 2014-ben készített időmérleg-felmérés sem mutatott jelentős összefüggést a gyermekszám és az önkéntes munkavégzés között. A gyermek nélküli megkérdezettek 34,3, az egygyermekes családok 33,5, a kétgyermekesek 36, míg a háromvagy többgyermekes családok 34,2\%-a számolt be önkéntes tevékenységéről (Váradi 2017). 
Molnár György és Kapitány Zsuzsa (2013) kutatási eredményei az önkéntesség és a gyermekvállalás tekintetében újszerü mintázatot mutatnak. Minél több, 15 éven aluli gyermeke van valakinek, annál valószínübb, hogy az egyén végez önkéntes tevékenységet. Feltehetőleg az önkéntes munkavégzés nagy arányban a gyermekek iskolájához vagy óvodájához, vagy akár szabadidős tevékenységéhez köthető.

Azonban nemcsak a gyermekek száma, hanem a háztartásban élők segítő attitűdje is hatással lehet az önkéntességre. Több mint nyolcszor nagyobb az esélye annak, hogy valaki önkéntes munkát vállaljon, ha a családjában valaki már végez, vagy korábban végzett hasonló tevékenységet (Molnár - Kapitány 2013).

Összességében látható, hogy a feltárt szakirodalom kiemeli a család és a házasság pozitív hatását az önkéntességre, emellett a gyermekszám növekedése sem befolyásolja negatívan az önkéntesség előfordulását. Azonban nem születtek kutatások arra vonatkozóan, hogy milyen összefüggés (együtt járás) lehet az önkéntesség és a fiatalok családtervei között. Kutatásunk újszerűsége tehát annak vizsgálata, hogy a párkapcsolati és gyermekvállalási tervek milyen kapcsolatban állhatnak az önkéntességgel, amelynek eredményeit a tanulmány empirikus részében mutatjuk be. Mivel a Család és karrier kutatás fő témája a fiatalok párkapcsolati és családtervei voltak, ezért regressziós elemzéseinkben az ezekre vonatkozó hatásokat tárjuk fel, az önkéntesség mint magyarázó változó szerepel benne, bár tudjuk, hogy az önkéntesség és családtervek között nem feltétlenül van ok-okozati összefüggés, illetve az ok és okozat fel is cserélődhet. Összességében azt feltételezzük, hogy egy általunk nem mért mögöttes ok, az altruizmus okozhatja a két tényező együtt járását.

\section{HIPOTÉZISEK}

H1: Mintánkban az egyetemisták önkéntes munkában való részvétele viszonylag alacsony szintű lesz, de növekvő trendeket mutat a 2010-es, Debreceni Egyetemen mért adatokhoz képest (lásd Fényes 2015).

H2: Az egyetemi évek alatt önkénteskedők körében a klasszikus altruista motivációk mellett megjelennek az új típusú, szakmai tapasztalatszerző motivációk is. Az altruista motiváció összefügghet a házasság (kontra élettársi kapcsolat) és a több gyermek tervezésével, hiszen a gyermekvállalásra is jellemző lehet az altruista motiváció, míg a karrierépítő önkéntesség inkább a kevésbé családközpontú diákokra lesz a jellemző. 
H3: Az egyetemi évek alatt önkéntes tevékenységet végzők inkább terveznek házasságot és több gyermeket, mint akik nem végeznek ilyen munkát, elsősorban az ingyenes többletmunka iránti vonzódás és az altruista attitűd miatt, amely az önkéntességre és a családtervekre is jellemző lehet.

H4: A nőkre, az idősebb és a vallásosabb hallgatókra inkább jellemző a házasság és a több gyermek tervezése (Engler 2018, Bacskai 2018).

H5: A diákok társadalmi háttere szintén hatással lehet a családtervekre. A falusi lakhellyel rendelkezők több gyermeket és inkább házasságot terveznek az erősebb tradicionális beállítottságuk miatt. Azonban az is fennállhat, hogy a rosszabb anyagi helyzetben levők, akik már eljutottak a felsőoktatásig, nem terveznek annyian házasságot és több gyermeket, mert anyagilag nem érzik megvalósíthatónak. Emellett az apa magasabb iskolai végzettsége hathat még pozitívan a származási család anyagi helyzetén keresztül a családtervekre. A család kulturális tőkéjét elsősorban az anyák közvetítik gyermekeik felé, és feltételezésünk szerint a magasabb végzettségü anyák még negatív irányba is befolyásolhatják a tervezett gyermekszámot, és a karrierépítést egyenrangú célként fogalmazhatják meg gyermekeik felé.

H6: A diákok hallgatótársaikkal való szorosabb kapcsolatrendszere növelheti a házasság tervezésének esélyét és a tervezett gyermekszámot, hiszen a jobb kapcsolatépítő készség segitheti a családtervezést, míg az elmagányosodás hátráltathatja azt.

\section{ADATOK, MÓDSZEREK ÉS VÁLTOZÓK}

Jelen tanulmány a Család és karrier kutatáson alapul, amely az EMMI Család- és Ifjúságügyért Felelős Államtitkárság, valamint a Három Királyfi, Három Királylány Alapítvány támogatásával valósult meg. Az adatfelvétel 2017-ben zajlott le 11 magyarországi felsőoktatási intézményben.' Az egyetemek kiválasztása során szakértői mintavétellel törekedtünk arra, hogy méret, régió és tudományterület² szerint reprezentatív legyen a minta. Az egyetemeken belül tudományterületenként véletlenszerüen kiválasztott szemináriumi csoportokat teljeskörüen kérdeztük le, biztosítva a minta valószínűségi jellegét.

\footnotetext{
'Eötvös Loránd Tudományegyetem, Óbudai Egyetem, Semmelweis Egyetem, Debreceni Egyetem, Debreceni Református Hittudományi Egyetem, Esterházy Károly Egyetem, Kaposvári Egyetem, Nyíregyházi Egyetem, Pécsi Tudományegyetem, Széchenyi István Egyetem, Szegedi Tudományegyetem.

${ }^{2}$ A tudományterületi felosztáshoz az MTA tudományterületi besorolását használtuk.
} 
A lekérdezés papíralapon történt a nappali tagozatos diákok körében (az alapsokaságba és a mintánkba nem kerültek be a frissen belépő elsőévesek, mivel kutatási kérdéseink szempontjából még nem rendelkeztek kiérlelt véleménnyel). Az eljuttatott 1600 kérdőívből 1502 értékelhető kérdőív érkezett vissza. Elemzéseinkben az adatbázis felhasználásával, az SPSS-program segítségével egyszerü megoszlásokat, kereszttábla-elemzést, klaszterelemzést, valamint logisztikus regresszió elemzéseket végeztünk.

A klaszterelemzést az önkéntesség motivációi3 mentén végeztük el (a motivációk alapmegoszlásait lásd az 5. táblázatban). A logisztikus regresszióinkban az első függőváltozónk a házasság kontra egyéb kapcsolatforma tervezése ${ }^{4}$, a második a tervezett gyermekszám ${ }^{5}$ kétértékű (átlag alatti és feletti terv) változója. Magyarázóváltozóink az önkéntesség az egyetemi évek alatt ${ }^{6}$, a nem, a kor, a vallásosság, az objektív anyagi helyzet index, a szubjektív anyagi helyzet ${ }^{8}$, az állandó lakóhely településének típusa, az apa és az anya elvégzett osztályainak száma, végül a kapcsolat a hallgatótársakkal index9

\footnotetext{
${ }_{3}^{3}$ Mennyiben motiváltak az alábbiak az önkéntes munkavégzésben? (1: egyáltalán nem 2: kis mértékben, 3: nagyobb mértékben, 4: teljes mértékben); Hogy segítsek másokon. Új ismeretek szerzése, szakmai fejlődés. Munkatapasztalat szerzése. Új ismerősök, barátok szerzése. Hogy jobban érezzem magam. Beírhassam az önéletrajzomba. Mert barátaim és családtagjaim is önkénteskedtek. Hitbéli meggyőződésem miatt.

${ }^{4} \mathrm{~A}$ változó részletes megoszlását lásd a 2. táblázatban.

${ }^{5} \mathrm{~A}$ változó részletes megoszlását lásd a 3. táblázatban.

${ }^{6}$ Végzett-e önkéntes munkát az egyetemi évei alatt? (igen/nem)

${ }^{7}$ 1: Van a hallgató családjának (1: van, 0: nincs, az indexet ezek összegéből képeztük) (Saját lakás, családi ház, Nyaraló, hobbitelek, Plazma-, LCD-televizió, Asztali számítógép vagy laptop otthoni internet-hozzáféréssel, Táblagép (tablet), e-book-olvasó, Mobilinternet (telefonon vagy táblagépen), Mosogatógép, Klíma, Okostelefon, Személyautó).

${ }^{8}$ Hogyan jellemeznéd családod anyagi helyzetét?

4: Mindenünk megvan, jelentősebb kiadásokra is telik (pl. nyaralás), megtakarítani is tudunk.

3: Mindenünk megvan, de nagyobb kiadásokat nem engedhetünk meg magunknak.

2: Elöfordul, hogy a mindennapi kiadásainkat nem tudjuk fedezni.

1: Gyakran megesik, hogy nincs pénzünk a mindennapi szükségletek fedezésére.

${ }^{9}$ Van-e olyan hallgatótársad, akire igazak az alábbiak? (van/nincs).

Akivel megbeszéled a tanulmányaiddal kapcsolatos problémáidat.

Akivel megbeszéled magánéleti problémáidat.

Akivel rendszeresen együtt töltöd a szabadidődet.

Akivel megbeszéled a jövöre vonatkozó terveidet.

Aki betegség esetén meglátogat vagy telefonon keres.

Akitől könyvet, jegyzetet, füzetet kérsz kölcsön.

Akivel tudományos kérdésekről beszélgetsz.

Akivel olvasmányélményeidről, kultúráról, közéleti kérdésekről beszélgetsz.

Akivel művészetről beszélgetsz.

Akivel együtt tanulsz.

Akivel megbeszéled a jövendő pályáddal kapcsolatos elképzeléseidet.
} 
1. táblázat: A vizsgált legfontosabb változók alapmegoszlásai, átlagai és szórásai

The distributions, means and standard deviations of the most important examined variables

Változó

Megoszlás (\%, átlag / szórás)

Végzett-e önkéntes munkát az egyetemi évei alatt?

igen

$38 \%$

nem

$62 \%$

Házasság kontra egyéb párkapcsolat tervezése

házasság

egyéb terv

A tervezett gyermekszáma ${ }^{a)}$

kettő vagy több

$67.9 \%$

kevesebb mint kettő

Nem

férfi

$43.6 \%$

nő

$56.4 \%$

Kor

$22.8 / 2.59$

Vallásosság

az egyház tanításait követi vagy a maga módján vallásos

$60.3 \%$

egyéb

$39.7 \%$

Objektív anyagi helyzet index (0-10)

$7.27 / 1.65$

Szubjektív anyagi helyzet (1-4)

$3.34 / 0.58$

Az állandó lakóhely településének típusa

város

falu

$25.8 \%$

Az apa elvégzett osztályainak száma (8-20)

$13.9 / 2.43$

Az anya elvégzett osztályainak száma (8-20)

$13.32 / 2.32$

Kapcsolatitőke-index (1-11)

$8.47 / 2.73$

a) Megjegyzés: a tervezett gyermekek számának átlaga 1,87 
2. táblázat: A párkapcsolati terv változó megoszlása, \%

Distribution of partnership plans variable, \%

Párkapcsolati tervek

Házasságot tervezek.

Együttélést tervezek, majd később házasságot.

csak együttélést tervezek.

Nem fogunk összeköltözni.

Nyitott kapcsolatunk lesz.

Semmilyen módon nem akarok elköteleződni.

Egyéb

Összesen, fő

a) Megjegyzés: a tervezett gyermekek számának átlaga 1,87

3. táblázat: A tervezett gyermekszám változó megoszlása, \% The distribution of the number of planned children variable, \%
Megoszlás, \%

43,41

43,93

7,58

0,44

1,69

1,10

1,84

$1359(100,00)$
Gyermekszám tervek

Egyáltalán nem szeretnék gyermeket.

Legalább egy gyermeket szeretnék.

Legalább két gyermeket szeretnék.

Három gyermeket szeretnék.

Négy vagy több gyermeket szeretnék.

Összesen, fő
Megoszlás, \%

$$
5,16
$$

47,95

15,47

4,50

$1222(100,00)$

Megjegyzés: a „még nem tudom” válaszokat adathiányként kezeltük.

Ezután megnéztük a regresszió két függőváltozója közötti kapcsolatot is, és szignifikáns összefüggést találtunk. A 4. táblázat szerint a házasságot tervezők 75,63\%-a tervez kettő vagy több gyermeket, míg az egyéb párkapcsolati formát tervezőknél ez az arány csak 60,22\%, összhangban a várakozásokkal. 
4. táblázat: A házasság és a gyermekszám tervek közti összefüggés, \%

The relationship between the plans of marriage and number of children, \%

\begin{tabular}{lccc} 
Megnevezés & $\begin{array}{c}\text { 0 vagy } 1 \text { gyermek } \\
\text { tervezése }\end{array}$ & $\begin{array}{c}2 \text { vagy több gyermek } \\
\text { tervezése }\end{array}$ & Összesen \\
\hline Házasság tervezése & 24,37 & 75,63 & 100,00 \\
Egyéb terv & 39,78 & 60,22 & 100,00 \\
N, fő & 385 & 799 & 1184 \\
\hline
\end{tabular}

Megjegyzés: a khi-négyzet próba 0,000 szinten szignifikáns.

\section{EREDMÉNYEK}

Eredményeink szerint a mintában szereplő diákok többsége saját bevallása szerint soha nem végzett önkéntes tevékenységet egyetemi évei alatt (mindössze $38 \%$ végzett). Az egyetemisták középiskolás korban végzett önkéntessége, önbevallásuk szerint valamivel nagyobb arányú volt (42\%), de ez fakadhat definíciós problémákból is, hogy mit értenek a diákok önkéntes munka alatt. Fontos megjegyezni, hogy a középiskolákban, a 2011-2012-ben bevezetett Iskolai Közösségi Szolgálat (ami definíciószerủen nem önkéntes munka, mivel kötelező) hatását még nem tükrözhetik adataink, hiszen a 2016/2017-es tanévben elsőéves egyetemista hallgatóknak van csak ilyen tapasztalata, de ők nem szerepeltek kutatásunk mintájában.

Ezután a diákok önkéntességének motivációit vizsgáltuk meg, de csak azoknál, akik bevallásuk szerint önkéntes munkát végeztek (38\%) egyetemi éveik alatt.

A legfontosabb motiváció a másokon való segítés, tehát a klasszikus altruista motiváció jelen van az egyetemisták körében (akárcsak a felnőtt lakosság körében). Majdnem ilyen erős motiváció azonban a munkatapasztalat-szerzés és a szakmai fejlődés, amely az új típusú önkéntesség jellemzője. Tehát a fiatalok önkéntességének motivációja inkább kevert; klasszikus és új típusú motivációk is megjelennek. A szakmai tapasztalatszerzés mellett a kapcsolatok épitése is fontos a fiatalok számára az önkéntes munkavégzés során (a negyedik legfontosabb motiváció az új ismerősök, barátok szerzése). 
5. táblázat: A diákok hány százalékát motiválták az alábbi szempontok az egyetem alatt végzett önkéntesség során (fontossági sorrendben), \%

The \% of students who were motivated by the given item, (in order by importance)

\begin{tabular}{lcccc}
\hline Motivációs szempont & $\begin{array}{c}\text { Egyáltalán } \\
\text { nem vagy kis } \\
\text { mértékben } \\
\text { motivált }\end{array}$ & $\begin{array}{c}\text { Nagyobb vagy } \\
\text { teljes mértékben } \\
\text { motivált }\end{array}$ & Összesen & N, fő \\
\hline $\begin{array}{l}\text { Hogy segítsek másokon } \\
\text { Új ismeretek szerzése, szakmai }\end{array}$ & 13,8 & 86,2 & 100,0 & 428 \\
fejlődés & 13,9 & 86,1 & 100,0 & 403 \\
Munkatapasztalat szerzése & 16,9 & 83,1 & 100,0 & 419 \\
Új ismerősök, barátok szerzése & 19,5 & 80,5 & 100,0 & 426 \\
Hogy jobban érezzem magam & 26,5 & 73,5 & 100,0 & 422 \\
Beírhassam az önéletrajzomba & 41,3 & 58,7 & 100,0 & 433 \\
Mert barátaim és családtagjaim & 60,9 & 39,1 & 100,0 & 430 \\
is önkénteskedtek & 64,4 & 35,6 & 100,0 & 433 \\
Hitbéli meggyőződésem miatt & &
\end{tabular}

Érdekes eredmény a lista végén szereplő három motiváció. Az önéletrajzba való beírhatóság egy, az USA-ban és Kanadában végzett vizsgálat szerint elsődleges az ott élő fiatalok körében (Handy et al. 2010), ám hazánkban e motiváció fontossága alacsony. Eszerint Magyarországon (és más kelet-közép-európai országban) a munkáltatók még nem veszik figyelembe az álásinterjún az önkéntességet olyan mértékben, mint nyugaton, az önkéntesség kultúrája még nem eléggé elterjedt a munkáltatók körében. Azonban feltehetőleg a magyar fiatalok sem annyira tudatosak ebből a szempontból, mint nyugati társaik (nem annyira jellemző rájuk egyfajta korai „karrierépítés”). Emellett a barátok és családtagok önkéntessége és ennek buzdító hatása sem jellemző a fiatalokra, ami szintén az önkéntesség kultúrájának hiányosságait mutatja. A lista végén szerepel az „egyházi” motivációjú önkéntesség, ami nyugaton szintén gyakoribb. Itthon a diákok kétharmadánál a hitbéli meggyőződés nem volt fontos motiváló tényező az önkéntességben.

Ha megnézzük egyenként a motivációk összefüggését a házasság tervezésével és a tervezett gyermekszámmal, csak a hitbéli meggyőződés motiváló erejénél voltak szignifikáns összefüggések10 (és ez volt a legkevésbé fontos motiváció, lásd fenn). Akiket ez a tényező nagyobb vagy teljes mértékben motivált, azokra

\footnotetext{
${ }^{10}$ Csak azokat tekintettük, akik végeztek önkéntes munkát egyetemi éveik alatt. A kereszttáblákban a párkapcsolati tervek esetén 420, a gyermekszám terveknél pedig 396 volt az elemszám, a khi-négyzet próba szignifikancia szintje pedig $p=0,000$ és $p=0,002$ volt.
} 
61,5\%-ban volt jellemző a házasság tervezése és 83\%-ukra a kettő vagy több gyermek tervezése, míg akiket ez a tényező egyáltalán nem vagy csak kismértékben motivált, azoknak csupán 39\%-a tervezett házasságot, de a kettő vagy több gyermek tervezésének aránya is kisebb volt (69\%). Mindez összhangban van a szakirodalommal és a várakozásainkkal.

Ezután a nyolc motiváció mentén klaszterelemzéssel csoportokat képeztünk a diákok körében. A várt segítő célú csoport (73fő) és a karrierépítő csoport (83fő) mellett volt egy harmadik csoport, akiknek a segítő szándék és a karrierépítés egyaránt fontos volt (164 fő), végül volt egy negyedik csoport is, akiknek mind a nyolc motiváció fontos volt (140 fö)."

6. táblázat: Az önkéntesség motivációi mentén képzett klaszterek (csak akik voltak önkéntesek egyetemi éveik alatt)

The four clusters based on the motivations of volunteering of students (only among those, who were volunteers during their studies)

\begin{tabular}{lcccc} 
& \multicolumn{4}{c}{ Klaszterek és klaszterközéppontok } \\
Motivációk & 1. & 2. & 3. & 4. \\
\cline { 2 - 5 } & 2,26 & 3,01 & 3,71 & 3,53 \\
Új ismeretek szerzése, szakmai fejlődés & 2,35 & 2,45 & 3,55 & 3,40 \\
Új ismerősök, barátok szerzése & 2,21 & 3,05 & 3,69 & 3,42 \\
Munkatapasztalat szerzése & 2,03 & 2,38 & 2,97 & 2,73 \\
Beírhassam az önéletrajzomba & 3,15 & 2,01 & 3,20 & 3,28 \\
Hogy jobban érezzem magam & 3,53 & 2,43 & 3,53 & 3,66 \\
Hogy segítsek másokon & 2,06 & 1,57 & 2,14 & 2,75 \\
Mert barátaim és családtagjaim is & 2,04 & 1,30 & 1,31 & 3,53 \\
$\quad$ önkénteskedtek & 73 & 83 & 164 & 140
\end{tabular}

Megjegyzés: K-Means klaszter, iteration 100, missing pairwise. A klaszter-középpontokat 2,5 felett szürkén jelöltük.

Ezután a klaszterbe tartozás és a házasság tervezése, valamint a tervezett gyermekszám kapcsolatát vizsgáltuk meg kereszttáblák segítségével, a házasság tervezésénél szignifikáns összefüggést kaptunk.

${ }^{11}$ A 2 és 3 klaszteres megoldás nehezen volt értelmezhető, ezért maradtunk a 4 klaszteres megoldásnál. 
Várakozásainkkal szemben csak a 3. és a 4. klaszternél volt jelentős különbség a házasság tervezésében, a minden motivációt fontosnak tartók körében felülreprezentált a házasságot tervezők aránya, míg a segítő és karrierépítő csoportban alulreprezentált. Ennek hátterében az állhat, hogy a hitbéli meggyőződés mint motiváló erő csak a minden motivációt fontosnak tartó klaszterben volt mérvadó, és mint már láttuk, ez a motiváló erő növeli a házasság tervezését a diákok körében.

7. táblázat: Az önkéntesség motivációi mentén képzett klaszterek és a házasság tervezésének összefüggései, \%

The relationship between motivation clusters and planning marriage among students, \%

\begin{tabular}{lccc}
\hline Klaszter & Házasság tervezése & Egyéb terv & Összesen \\
\hline 1. Segítő célúak & 43,28 & 56,72 & 100,00 \\
2. Karrierépítő célúak & 47,50 & 52,50 & 100,00 \\
3. Segító és karrierépítők & 36,65 & 63,35 & 100,00 \\
4. Motiváltak & 59,40 & 40,60 & 100,00 \\
N, fő & 205 & 236 & 441
\end{tabular}

Megjegyzés: a khi-négyzet próba 0,001 szinten szignifikáns, ha az adj-reziduals nagyobb volt, mint 2, azt szürke háttérrel jelöltük.

\section{A házasság és a gyermekszám tervezésére ható okok többváltozós elemzése}

Azt, hogy az egyén milyen és mekkora ún. „önkéntességi tőkével” rendelkezik - azaz mennyire hajlandó a jövőben önkéntes munkát végezni, vagy végzett-e a múltban -, jelentős mértékben meghatározza a szülők által örökitett gazdasági és kulturális tőke nagysága (Youssim et al. 2014). Empirikus munkánkban azonban azt vizsgáljuk, hogy a családtervekkel kapcsolatban kimutatható-e összefüggés aszerint, hogy a diák végzett-e önkéntes munkát egyetemi tanulmányai alatt, kiszűrve a diák anyagi, kulturális és kapcsolati erőforrásainak hatását a házasságkötési és a gyermekszám-tervekre. 
8. táblázat: Házasság tervezése (a diákok 43\%-a) mint függôváltozóra ható okok (logisztikus regresszió, exp (B)-k)

The effects on planning marriage by logistic regression method (exp B)

$\begin{array}{ll}\text { Magyarázó változók } & \text { Exp(B) } \\ \text { Önkéntes munka } & 1,04 \\ \text { Nem } & 1,24 \\ \text { Kor } & 0,99 \\ \text { Vallásosság } & 1,92^{* * *} \\ \text { Objektív anyagi helyzet } & 0,95 \\ \text { Szubjektív anyagi helyzet } & 1,4^{*} \\ \text { Az állandó lakóhely településének típusa } & 0,74 \\ \text { Az apa elvégzett osztályainak száma } & 1,09^{*} \\ \text { Az anya elvégzett osztályainak száma } & 0,98 \\ \text { Kapcsolatok } & 1,08^{*} \\ \text {-2 log-likelihood csökkenése, \% } & 4,1\end{array}$

Megjegyzés: Exp (B) értékek mellett tüntettük fel a Wald statisztika szignifikanciáját, ${ }^{* * *}$ jelöli a 0,000 alatti, ${ }^{* *}$ a 0,001 és 0,01 közötti, * jelöli a 0,01 és 0,05 közötti szignifikanciát.

A házasság tervezése és az önkéntesség között nem volt szignifikáns összefüggés, szemben a hipotézisünkben állítottakkal (8. táblázat). Azonban a vallásosság (a vallásosak és a maguk módján vallásosak közösen) növelte a házasság tervezését, összhangban a szakirodalommal és hipotézisünkkel. A diákok családjának jobb szubjektív anyagi helyzete szintén növeli a házasság tervezésének esélyét. Az apák magasabb iskolai végzettsége, ami szintén a jobb anyagi helyzettel függhet össze, szintén növelte a házasság tervezését. Emellett kimutatható, hogy a jobb hallgatói kapcsolatok szintén pozitivan befolyásolták a házassági terveket. Azonban a házasság tervezésére - szemben a szakirodalommal - nem hatott a nem és a kor, a településtípus, illetve az anya iskolázottsága sem, ám a diák anyagi helyzeténél a szubjektív anyagi helyzet hatott, az objektív helyzet viszont nem (ez utóbbit a család tartós fogyasztási cikkekkel való rendelkezésével mértünk). Összességében azonban a modell magyarázóereje elég alacsony, így a fenti szignifikáns hatások gyengék. 
9. táblázat: A tervezett gyermekszám (kétértékü változó) mint függőváltozóra ható okok (logisztikus regresszió, exp (B)-k) (a diákok 67,9\%-a tervez az átlagosnál több, kettő vagy több gyermeket) The effects on the number of planned children by logistic regression method (exp B)

\begin{tabular}{ll}
\hline Magyarázó változók & Exp(B) \\
\hline Önkéntes munka & $1,46^{*}$ \\
Nem & 0,94 \\
Kor & 0,99 \\
Vallásosság & $1,88^{* *}$ \\
Objektív anyagi helyzet & 0,93 \\
Szubjektív anyagi helyzet & 1,38 \\
Az állandó lakóhely településének típusa & 0,85 \\
Az apa elvégzett osztályainak száma & 1,00 \\
Az anya elvégzett osztályainak száma & 1,05 \\
Kapcsolatok & 1,05 \\
-2 log-likelyhood csökkenése, \% & 3,6
\end{tabular}

Megjegyzés: Exp (B) értékek mellett tüntettük fel a Wald statisztika szignifikanciááát, ${ }^{* * *}$ jelöli a 0,000 alatti, ${ }^{* *}$ a 0,001 és 0,01 közötti, * jelöli a 0,01 és 0,05 közötti szignifikanciát.

A második regressziós futtatásunkból látható, hogy aki végzett önkéntes munkát egyetemi évei alatt, nagyobb eséllyel tervez kettő vagy több gyermeket, mint csak egyet vagy egyet sem, és ez összhangban van hipotézisünkkel (9. táblázat). Mint tudjuk, a vallásosság növeli az önkéntesség előfordulását a szakirodalom szerint, illetve a szakirodalom és a mi fenti eredményeink szerint is a vallásosság a tervezett gyermekszámra is pozitívan hat. Itt azonban a vallásosság hatása mellett is van együtt járás az önkéntesség és az átlag feletti gyermekszám-tervek között. Eszerint tehát nem csak azért terveznek több gyermeket az önkénteskedők, mert vallásosak, hanem a vallásosság hatásán túl is együtt jár a több gyermek tervezése és az önkéntes aktivitás.² Összességében azonban itt is elég kicsi a modell magyarázóereje, tehát a hatások gyengék, és nem hatott az átlagosnál több gyermek tervezésének esélyére a kor, a nem, az apa és az anya iskolázottsága, a településtípus, az objektív anyagi helyzet, valamint a kapcsolatok sem. (A jobb szubjektív anyagi helyzet kicsit növelte a két vagy több gyermek tervezésének esélyét, de csak p=0,062 szinten volt szignifikáns).

\footnotetext{
${ }^{12}$ Ez az eredmény pontosítja az önkéntesség motivációnál kapott kereszttáblás eredményt, miszerint csak a hitbéli meggyőződés mint az önkéntességet motiváló erő növelte a tervezett gyermekszámot.
} 


\section{ÖSSZEGZÉS ÉS KÖVETKEZTETÉSEK}

Dolgozatunkban a felsőoktatási hallgatók önkéntessége és családtervei közti összefüggéseket vizsgáltuk meg. Eddig elsősorban a családi állapot és gyerekvállalás valamint az önkéntesség kapcsolatát vizsgálta a szakirodalom, mi azonban a diákok családterveit hozzuk összefüggésbe az önkéntességgel. Fő hipotézisünk, hogy egy általunk nem mért mögöttes ok, az altruizmus okozhatja a két tényező együtt járását. Emellett az elméleti részre épitve több részhipotézist is megfogalmaztunk.

Összhangban első hipotézisünkkel, adataink szerint az önkéntesség aránya elég kicsi a hallgatók körében, a diákok csupán 38\%-a volt önkéntes egyetemi tanulmányai alatt. A tendencia azonban feltehetőleg növekvő (v.ö. Fényes [2015] adataival, ahol 2010-ben a Debreceni Egyetem hallgatóinak 26\%-a volt önkéntes egyetemi évei alatt).

Második hipotézisünk már az önkéntesség motivációi és a családtervek öszszefüggésére vonatkozott. A motivációk mentén képzett hallgatói csoportok (klaszterek) azonban csak a házasság tervezésében különböztek, de itt is a várakozásokkal szemben nem a tisztán segitőcélú csoportra jellemző inkább a házasság tervezése, hanem a vegyes motivációjú (mind a nyolc motivációt fontosnak tartó) csoportra. A motivációkat külön-külön tekintve pedig a várakozásokkal összhangban a hitbéli meggyőződést fontos motiváló erőnek tartó hallgatókra volt inkább jellemző a házasság és a kettő vagy több gyermek tervezése.

Harmadik hipotézisünk is részben teljesült. Az önkéntesség nem függött öszsze a házassági tervekkel, de a gyermekszámmal igen. Ennek oka lehet, hogy a több gyermek tervezése és az önkéntesség mögött is egyfajta altruista attitüd állhat, és ez okozhatja a két változó együtt járását. (A házasságnál eszerint nem áll fenn ez az összefüggés.)

Negyedik hipotézisünk is csak részben teljesült. Eredményeink szerint a nők nem terveznek gyakrabban házasságot és több gyermeket, szemben Engler (2018) eredményeivel. Ennek oka lehet, hogy itt többváltozós elemzést végeztünk, és kimutattuk, hogy a vallásosságnak pozitív hatása van a családtervekre, továbbá feltételezhetjük, hogy a nők nagyobb arányban vallásosak, mint a férfiak. Annak oka, hogy a kor sem számított, az lehet, hogy a mintában a diákok életkora nagyjából hasonló volt. Ahogy már jeleztük, fontos eredmény, hogy a vallásosságnak mindkét regressziós modellben szignifikáns hatása volt a családtervekre, összhangban a szakirodalommal, amit elsősorban a vallásos hallgatók konzervatívabb értékvilágával indokolhatunk. 
Ötödik hipotézisünk a diákok társadalmi hátterének hatását vizsgálta a családtervekre, de ezek a háttértényezők hipotézisünkkel szemben csak a házasság kontra egyéb párkapcsolati terveket befolyásolták. Azon hipotézisünk, hogy a falusi lakhellyel rendelkezők több gyermeket és inkább házasságot terveznek, illetve hogy a magasabb végzettségủ anyák még negatív irányba is befolyásolhatják a tervezett gyermekszámot, nem teljesült. Viszont a jobb szubjektív anyagi helyzet (hogy rendszeresen tudtak megtakarítani) és az apák magasabb iskolázottsága növelték a házasság tervezésének esélyét. A rosszabb anyagi hátterü, alacsonyabb iskolázottságú apákkal rendelkező diákok tehát kevésbé terveztek házasságot, feltehetőleg anyagi okok miatt.

Hatodik hipotézisünk a diákok hallgatótársakkal való kapcsolatrendszerére vonatkozott. Eredményeink szerint a diáktársakkal való szorosabb kapcsolat növelte a házasság tervezésének esélyét. Hipotézisünkkel összhangban tehát az elmagányosodás és a hallgatókkal való lazább kapcsolat csökkenti a házasodási terveket. A tervezett gyermekszámmal azonban nem függött össze a hallgató intragenerációs kapcsolatrendszerének erőssége.

Összességében elgondolkodtató, hogy miért ilyen alacsony az önkéntesség aránya a magyar fiatalok körében. Emellett, a vizsgálat szerint az önkéntesség kultúrája nem elég elterjedt a munkáltatók, de a barátok és a diákok családtagjai körében sem. Korábbi munkánkban kimutattuk (Fényes - Markos 2016), hogy az önkéntesség a felsőoktatásban segíti a diákok szakmai fejlődését, tanulmányi előrehaladását, fejleszti az életben szükséges készségeket (pl. munkára szocializál, és főleg az új típusú önkénteseknek később könnyebb az elhelyezkedés), fejleszti az állampolgári tudatosságot és felelősségvállalást is. Ebben a tanulmányban kimutattuk, hogy aki önkénteskedett egyetemi évei alatt, nagyobb eséllyel tervez több gyermeket is. Eredményünk hátterében az önkéntesség és a több gyermek tervezésének közös altruista attitüdje állhat. Az altruizmus, a tolerancia és a segítőkészség fejlesztése a diákokban tehát mindkét tényezőre pozitivan hathat. Fontos megjegyezni azonban azt is, hogy itt csak a házasság és az átlagosnál több gyermek tervezését vizsgáltuk, és mint azt a szakirodalomból tudjuk, ezek a tervek nem biztos, hogy meg is valósulnak. 


\section{IRODALOM}

Bacskai Katinka 2018: A vallásosság hatása a családalapítással és a gyermekvállalással kapcsolat attitüdökre. In Engler Ágnes (szerk.) Család és karrier. Egyetemi hallgatók jövőtervei. Oktatáskutatók könyvtára 3. Debrecen, Felsőoktatási Kutató és Fejlesztő Központ, 191-202.

Bartal Anna Mária 2008: Önkéntesek és nem-önkéntesek jellemzői a 2008. évi Európai értékvizsgálat tükrében. http://volunteermotivation.info/downloads/ONK_NEMONK_ BAM2009.pdf. Letöltve: 2018. 06. 25.

Bartal Anna Mária 2010: Önkéntesek és nem-önkéntesek a 2008. évi Európai Érték Vizsgálat tükrében, avagy Aki önkéntes nagyobb valószinüséggel boldogabb és elégedettebb? http://volunteermotivation.info/downloads/ONK_NEMONK_BAM2009.pdf. Letöltve: 2018. 06. 01.

Bocsi Veronika 2018: Karrier családdal vagy karrier egyedül? In Engler Ágnes (szerk.): Család és karrier. Egyetemi hallgatók jövőtervei. Oktatáskutatók könyvtára 3. Felsőoktatási Kutató és Fejlesztő Központ, Debrecen, 85-110.

Cnaan, Ram A. - Amrofell, Laura M. 1994: Mapping Volunteer Activity. Nonprofit and Voluntary Sector Quarterly, 23(4), 335-351.

Czike Klára - Bartal Anna Mária 2004: Nonprofit szervezetek és önkéntesek - új szervezeti típusok és az önkéntes tevékenységet végzök motivációi. http://docplayer. hu/21088013-Nonprofit-szervezetek-es-onkentesek-uj-szervezeti-tipusok-es-azonkentes-tevekenyseget-vegzok-motivacioi.html. Letöltve: 2018. 01. 09.

Czike Klára - Kuti Éva 2006: Önkéntesség, jótékonyság, társadalmi integráció. Nonprofit Kutatócsoport és Önkéntes Központ Alapítvány, Budapest.

Czike Klára - Szabóné Ivánku Zsuzsanna 2010: Online kutatás az önkéntességröl a lakosság körében. Önkéntes Központ Alapítvány.

Dekker, Paul - Halman, Loek 2003: Volunteering and Values: An Introduction. In Dekker, Paul - Halman, Loek (eds.): The Values of Volunteering. Cross-Cultural Perspectives. Kluver Academic/Plenum Publishers, New York, Boston, Dordrecht, London, Moscow, 1-18.

Einolf, Christopher - Philbrick, Deborah 2014: Generous or Greedy Marriage? A Longitudinal Study of Volunteering and Charitable Giving. Journal of Marriage and Family, 76(3), 573-586.

Engler Ágnes 2014: Dilemmák felsőfokon - hallgatók családalapítási tervei. A Nemzeti Család- és Szociálpolitikai Intézet Folyóirata, 13(1), 17-25.

Engler Ágnes 2018: Magyar egyetemisták szakmai és magánéleti jövőtervei. In Engler Ágnes (szerk.): Család és karrier. Egyetemi hallgatók jövőtervei. Oktatáskutatók könyvtára 3. Felsőoktatási Kutató és Fejlesztő Központ, Debrecen, 5-11.

European Youth 2018: http://ec.europa.eu/commfrontoffice/publicopinion/flash/fl_408_en.pdf. Letöltve: 2019. 01. 23.

Fényes Hajnalka 2015: Önkéntesség és új típusú önkéntesség a felsőoktatási hallgatók körében. Debreceni Egyetemi Kiadó, Debrecen. 
Fényes Hajnalka - Lipcsei László - Szeder Dóra Valéria 2012: Önkéntesség a Debreceni Egyetem hallgatói táborában. In Dusa Ágnes - Kovács Klára - Márkus Zsuzsanna Nyüsti Szilvia - Sőrés Anett (szerk.): Egyetemi élethelyzetek. Ifjúságszociológiai tanulmányok II. Debreceni Egyetemi Kiadó, Debrecen, 99-120.

Fényes Hajnalka - Markos Valéria 2016: Az intézményi környezet hatása az önkéntességre. In Pusztai Gabriella - Bocsi Veronika - Ceglédi Tímea (szerk.): A felsőoktatás (hozzáadott) értéke. Partium - P.P.S.-Ú.M.K., Nagyvárad-Budapest, 248-261.

Fináncz Judit 2018: Családalapítási és jövőtervek regionális megközelítésben. In Engler Ágnes (szerk.): Család és karrier. Egyetemi hallgatók jövőtervei. Oktatáskutatók könyvtára 3. Felsőoktatási Kutató és Fejlesztő Központ, Debrecen, 41-59.

Granovetter, Mark S. 1973: The strength of weak ties. American Journal of Sociology, 78(6), 1360-1380.

Granovetter, Mark S. 1983: The Strength of Weak Ties. A Network Theory Revisited. Sociological Theory, 1, 201-233.

Handy, Femida, - Cnaan, Ram A. - Hustinx, Lesley - Kang, Chulhee - Brudney, Jeffrey L. - Haski Leventhal, Debbie - Holmes, Kristen - Meijs, Lucas C. - Pessi, Anne B. Ranade, Bhagyashree - Yamauchi, Naoto - Zrinscak, Sinisa 2010: A Cross-Cultural Examination of Student Volunteering: Is It All About Résumé Building? Nonprofit and Voluntary Sector Quarterly, 3., 498-523.

Hustinx, Lesley 2001: Individualizational and New Styles of Youth Volunteering: an Empirical Exploration. Voluntary Action, 2., 57-76.

Juknevicius, Stanislovas - Savicka, Aida 2003: From Restitution to Innovation: Volunteering in Postcommunist Countries. In Dekker, Paul - Halman, Loek (eds.): The Values of Volunteering. Cross-Cultural Perspectives. Kluver Academic/Plenum Publishers. New York, Boston, Dordrecht, London, Moscow, 127-141.

Kapitány Balázs 2002: Gyermekvállalási kedv Magyarországon. In Pongrácz Tiborné Spéder Zsolt (szerk.): Népesség - értékek - vélemények. KSH Népességtudományi Kutatóintézet, Budapest, 23-34.

Kapitány Balázs - Spéder Zsolt 2018: Gyermekvállalás. In Monostori Judit - Őri Péter - Spéder Zsolt (szerk.): Demográfiai Portré 2018. Jelentés a magyar népesség helyzetéröl. KSH Népességtudományi Kutatóintézet, Budapest, 47-64.

Kopp Mária - Skrabski Árpád 2003: A gyermekvállalás pszichológiai és szociális háttértényezői a magyar népesség körében. Demográfia, 46(4), 383-395.

KSH 2012: A gyermekvállalás társadalmi-gazdasági hátterének területi jellemzői. https://www.ksh.hu/docs/hun/xftp/idoszaki/regiok/szegedgyermekvallalas.pdf. Letöltve: 2018. 04. 22.

KSH 2016: Az önkéntes munka jellemzői. https://www.ksh.hu/docs/hun/xftp/idoszaki/ pdf/onkentes.pdf. Letöltve: 2018. 06. 05.

Lancee, Bram - Radl, Jonas 2014: Volunteering over the Life Course. Social Forces, 93(2), 833-862.

Li, Y. 2007: Recovering from spousal bereavement in later life: Does volunteer participation play a role? Journal of Gerontology: Social Sciences, 62(4), 257-266.

Nesbit Rebecca 2011: The Influence of Major Life Cycle Events on Volunteering. Nonprofit and Voluntary Sector Quarterly, 41(6), 1153-1174. 
Markos Valéria 2018: Az önkéntes és fizetett munkát végző hallgatók családi hátterének és munkaérték preferenciáinak vizsgálata). PedActa, 8(2), 1-16.

Mohácsi Márta - Juhász Tímea 2017: Karrier és családtervezési kérdések feltárása nappali tagozatos egyetemi hallgatók körében empirikus vizsgálat alapján. In Resperger Richárd, Czeglédy Tamás (szerk.): Geopolitikai stratégiák Közép-Európában [nemzetközi tudományos konferencia, Sopron, 2017. november 9.]: Tanulmánykötet. Soproni Egyetem Kiadó, Sopron, 379-389.

Molnár György - Kapitány Zsuzsa 2013: Munkahely a közszférában. Biztonság és hivatás, a szubjektív szempontok szerepe. Közgazdasági Szemle, 6(7-8), 781-813.

Monostori Judit - Murinkó Lívia 2018: Háztartás- és családszerkezet. In Monostori Judit Őri Péter - Spéder Zsolt (szerk.): Demográfiai Portré 2018. Jelentés a magyar népesség helyzetéröl. KSH Népességtudományi Kutatóintézet, Budapest, 177-198.

Murinkó Lívia - Rohr Adél 2018: Párkapcsolat, házasságkötés. In Monostori Judit - Őri Péter - Spéder Zsolt (szerk.): Demográfiai Portré 2018. Jelentés a magyar népesség helyzetéről. KSH Népességtudományi Kutatóintézet, Budapest, 9-28.

Perpék Éva 2012: Formal and Informal Volunteering in Hungary: Similarities and Differences. Corvinus Journal of Sociology and Social Policy, 3(1), 59-80.

Pongrácz Tiborné - S. Molnár Edit 2011: Nemi szerepek és a közvélemény változásának kölcsönhatása. In Nagy Ildikó - Pongrácz Tiborné (szerk.): Szerepváltozások: jelentés a nők és férfiak helyzetéről. TÁRKI - Nemzeti Erőforrás Minisztérium, Budapest, 192206.

Pusztai Gabriella - Fényes Hajnalka 2014: Önkéntesség és vallásosság összefüggései eltérő felekezeti kompozíciójú közegekben. In Pusztai Gabriella - Lukács Ágnes (szerk.): KözössÉGteremtök. Tisztelgés a magyar vallásszociológusok nagy nemzedéke elött. Debreceni Egyetemi Kiadó, Debrecen, 329-350.

Reed, Paul - Selbee, Kelvin 2001: The civic core in Canada: disproportionality in charitable giving, volunteering and civic participation. Nomprofit and Voluntary Sector Quarterly, 30(4), 761-780.

Rohr Adél 2017: Vélemények a házasságról és az élettársi kapcsolatról Magyarországon, a rendszerváltást követő 25 évben. Demográfia, 60(2-3), 173-195.

Rotolo, Thomas - Wilson, John 2006: Employment Sector and Volunteering: The Contribution of Nonprofit and Public Sector Workers to the Volunteer Labor Force. Sociological Quarterly, 47(1), 21-40.

Ruiter, Stijn - de Graaf, Nan Dirk 2006: National Context. Religiosity, and Volunteering: Results from 53 Countries. American Sociological Review, 71(2), 191-210.

Somlai Péter 2013: Család 2.0. Együttélési formák a polgári családtól a jelenkorig. Napvilág Kiadó, Budapest.

Somlai Péter - Tóth Olga 2002: A házasság és a család változásai az ezredforduló Magyarországán. Educatio, 11(3), 339-349.

Váradi Rita 2017: Az önkéntes munka jellemzői a munkaerő-felmérés alapján. In Háztartási munka, önkéntes munka, láthatatlan munka, 1. https://www.ksh.hu/docs/ hun/xftp/idoszaki/pdf/lathatatlan_munka_1.pdf. Letöltve: 2018. 05. 09. 
Voicu, Malina - Voicu, Bogdan 2003: Volunteering in Romania: A Rara Avis. In Dekker, P. - Halman, L. (eds.): The Values of Volunteering. Cross-Cultural Pers-pectives. Kluver Academic/ Plenum Publishers, New York, Boston, Dordrecht, London, Moscow, 143-160.

Volunteurope 2018: Measuring the impact of volunteering. Position Paper. https:// volonteurope.eu/wp-content/uploads/2018/03/Measuring-impact-_Paper_Final.pdf. Letöltve: 2019.01.10.

Wilson, John 2000: Volunteering. Annual Review of Sociology, 26(1), 215-240.

Wilson, John - Musick, Marc 1997: Who Cares? Toward an Integrated Theory of Volunteer Work. American Sociological Review, 62(5), 694-713.

Wollebek, Dag - Selle, Per 2003: Generations and Organizational Change. In Dekker, Paul - Halman, Loek (eds.): The Values of Volunteering. Cross-Cultural Perspectives. Kluver Academic/Plenum Publisher, New York, Boston, Dordrecht, London, Moscow, 161-179. Youssim, Iaroslav - Hank, Karsten - Litwin, Howard 2014: The Role of Family Social Background and Inheritance in Later Life Volunteering: Evidence From SHARE-Israel. Research on Aging, 37(3), 3-17. 


\title{
THE RELATIONSHIP BETWEEN HIGHER EDUCATION STUDENTS' VOLUNTEERING AND THEIR FAMILY PLANS
}

\begin{abstract}
In our paper we examine in the framework of "Család és karrier" research, whether there is a relationship between volunteering of higher education students and family planning, namely planning marriage or more children. Our hypothesis is that volunteering and planning more children both need some kind of altruistic attitude, and that's why these two variable correlate. Our regression model show, that students planned marriage more if they are religious, if their family is in better financial situation, if their father is more educated, and finally if the student had better relationship with other students. But volunteering correlated with planning more children, beside the positive effect of religiosity on these plans. We suppose that increasing altruism, tolerance and helping attitude among students could affect their family plans and also their volunteering activity, positively. But we have to note that we examined only family plans, and based on the literature, we suppose that these plans not certainly be realized in the future.
\end{abstract}

